\title{
THE STUDY OF PRODUCTION REGIMES AND QUALITY PARAMETERS OF EXTRUDED FEED ADDITIVE BASED ON CORN SEED AND SUBSTANDARD EGG MASS
}

\author{
Bogdan Iegorov \\ Department of Technology of Mixed Feed and Biofuel \\ Odessa National Academy of Food Technologies \\ 112 Kanatnaya str., Odessa, Ukraine, 65039 \\ bogdan_egoroff@list.ru \\ Nina Vorona \\ Department of Technology of Mixed Feed and Biofuel \\ Odessa National Academy of Food Technologies \\ 112 Kanatnaya str., Odessa, Ukraine, 65039 \\ tarnin@te.net.ua \\ Alla Makarynska \\ Department of Technology of Mixed Feed and Biofuel \\ Odessa National Academy of Food Technologies \\ 112 Kanatnaya str., Odessa, Ukraine, 65039 \\ alla.makarinskaya@yandex.ru \\ Olena Voietska \\ Department of Technology of Mixed Feed and Biofuel \\ Odessa National Academy of Food Technologies \\ 112 Kanatnaya str., Odessa, Ukraine, 65039 \\ vecombi@yandex.ua \\ Tatiana Bordun \\ Department of Technology of Mixed Feed and Biofuel \\ Odessa National Academy of Food Technologies \\ 112 Kanatnaya str., Odessa, Ukraine, 65039 \\ borduntv@yandex.ua
}

\footnotetext{
Abstract

On the base of practical studies were established the rational parameters of technological processes of production of extruded feed additive. There was determined an expedience of mixture of substandard chicken egg mass and the crushed corn seed in two stages in frame (during $18 \mathrm{~s}$ ) and blade (during 120...180 s) mixers. There were determined the optimal regimes of mixture extruding: pressure in working zone of extruder $2 \ldots 3 \mathrm{mPa}$, consumed force of electric motor $4,0 \ldots 4,5 \mathrm{~kW}$, temperature on outcome of extruder $110 \ldots 120^{\circ} \mathrm{C}$, duration of process $60 \ldots 120 \mathrm{~s}$, diameter of matrix port $10 \mathrm{~mm}$.

There were given the results of study of parameters of quality and nutritive value of extruded feed additive. It was established, that in the process of extruding the quality parameters of food additive are improved at the expense of dextrinization and gelatinization of starch, decrease of bacterial and fungal pollution, disinfection of product.

There was proved a possibility to solve problem of utilization of defective eggs at feeding poultry

Keywords: extruded feed additive; rational parameters of processes; substandard egg mass; technological processes of extruding and mixing.

\section{Introduction}

Last 5 years in mixed fodder industry of the world was marked the course on the rise of requirements to the quality and safety of mixed fodder production [1-3]. 
At the same time there was observed the decrease of nutritive value of the raw material for production of the ready goods [4]. In this connection scientists and practicians throughout the world search for possibility to use the new fodder means that would lead to reduction of prices of mixed fodders and cattle-breeding production.

In Ukraine are produced near 100000 tones of substandard egg mass annually [5, 6], that is often missed because of significant cost of its processing [7, 8]. There is a possibility to use substandard chicken eggs without shell as a source of animal protein in composition of mixed fodders for poultry, namely for production of extruded feed additive (EFA). Technological method of EFA production provides getting of homogenous mixture of crushed corn seed and substandard egg mass and extruding of mixture [9].

The studies were aimed at establishing of the optimal parameters of processes of mixing and extruding of corn seed and substandard egg mass under conditions of the best quality parameters of EFA.

\section{Materials and methods of research}

Theoretical and practical studies on the topic were carried out in Odessa national academy of nutritive technologies (Ukraine). Experimental studies were carried out on the base of departments of mixed fodders and biofuels, biochemistry, microbiology and physiology of nutrition and also laboratory of biochemistry of Odessa selection-genetic institute of National center of seed and sort studies of NAAS of Ukraine.

The process of mixing egg mass without shell and crushed seed raw material for getting highly homogenous feed additive enriched with protein was carried out in frame mixer (Fig. 1) and in mixer of periodic action with blade mixing device (Fig. 2, 3) [10].
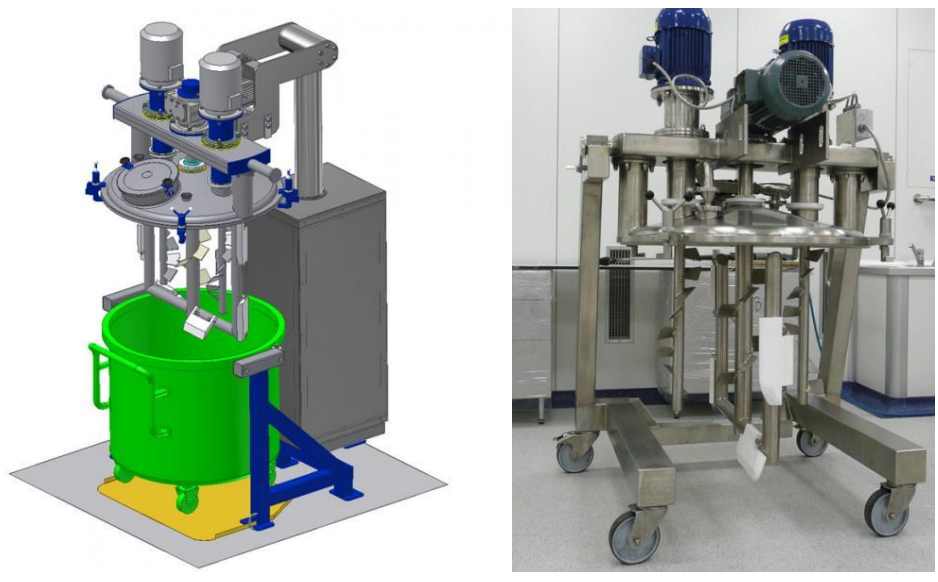

Fig. 1. Frame mixer with scraper (Kates, Poland)

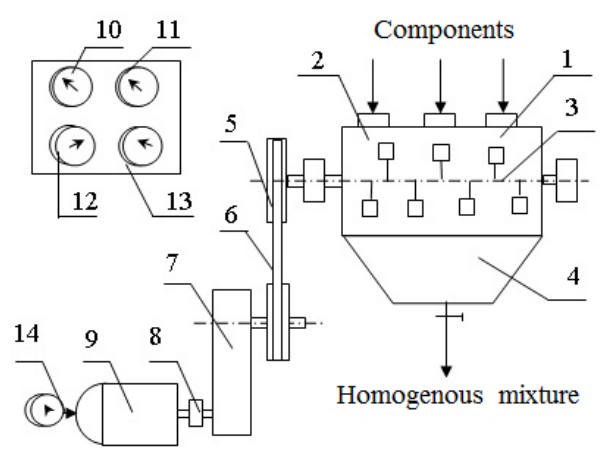

Fig. 2. Scheme of experimental stand for the study of technological mixing process:

1 - bath of mixer, 2 - loading port, 3 - shaft of mixing device, 4 - bunker, 5 - pulley on shaft of mixing device, 6 - wedge-belt transmission, 7 - worm reducer, 8 - coupling box,

9 - electric motor, 10 - voltmeter, 11 - ammeter, 12 - LATR, 13 - timer, 14 - tachometer TC-45 


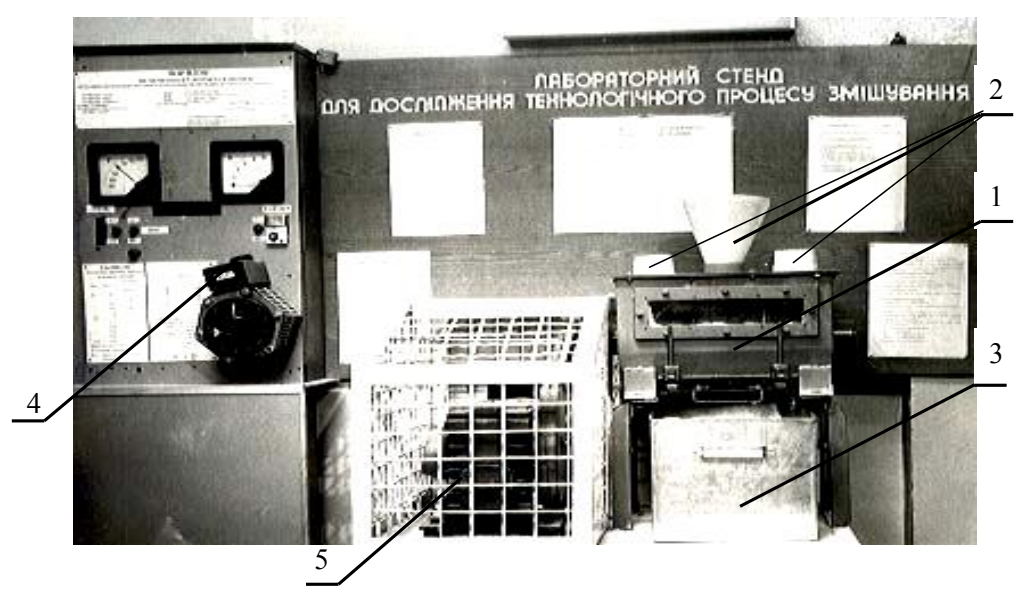

Fig. 3. Laboratory stand for study of technological mixing process: 1 - mixer, 2 - loading pipes, 3 - unloading tray, 4 - control desk, 5 - electricity cable

The part of crushed seed raw material and homogenous egg mass without shell was dosed and mixed in frame mixer during $180 \mathrm{~s}$ in 1:1 ratio for even distribution of liquid raw material in mixture.

Preliminary prepared components were loaded in bath of the 1 mixer through the loading ports starting from the main part of crushed seed raw material that is included in the content of feed additive in maximal amount and finishing with preliminary mixture that is included in the content of feed additive in minimal amount. The components were mixed in laboratory mixer during $60 \ldots 360 \mathrm{~s}$ at the equal frequency of rotation of mixer working organ $n=1,33 \mathrm{~s}^{-1}$. After finishing of process the hatch was open for unloading the mixture components in bunker 4. The homogeneity of components distribution in mixture content was assessed by the node component (beta-carotene) that is included in the content in minimal amount. The assessment of efficiency of the mixing process was carried out by heterogeneity coefficient $\left(\mathrm{V}_{c}\right)$ of distribution of egg mass without shell in mixture depending on time of mixing (1) [11]:

$$
\mathrm{V}_{\mathrm{c}}=\frac{1}{\overline{\mathrm{x}}} \sqrt{\frac{\sum_{\mathrm{i}=1}^{\mathrm{n}}\left(\mathrm{x}_{\mathrm{i}}-\overline{\mathrm{x}}\right)^{2}}{\mathrm{n}-1}} \cdot 100, \%
$$

where $\overline{\mathrm{x}}$ - mean arithmetical observation of values that is the mean content of node component in samples; $\mathrm{x}_{\mathrm{i}}$ - random value in в $\mathrm{i}$-th experience; $\mathrm{n}$ - number of selected samples.

Technological process of extruding was carried out on extruder of EX-150 (Bronto, "Cherkaselevmotormach", Ukraine) (Fig. 4) [12].
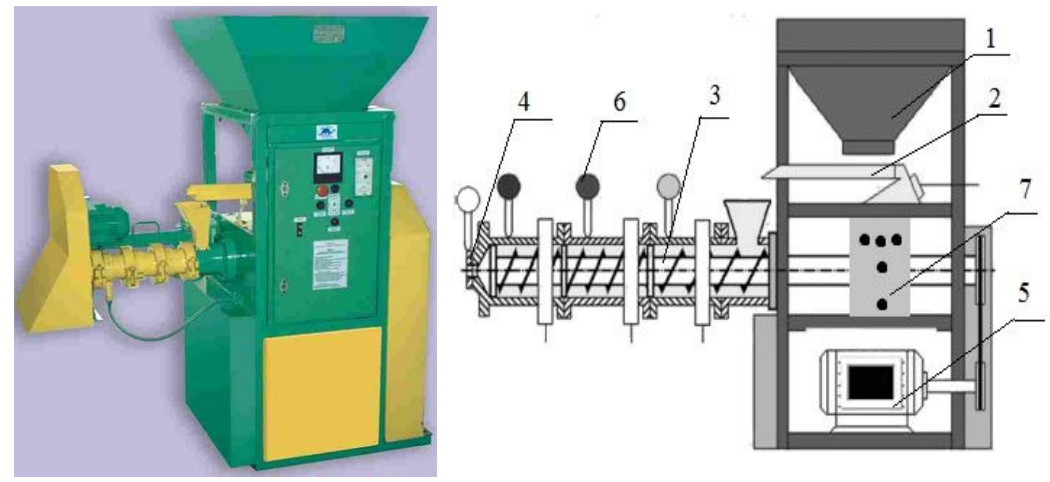

Fig. 4. Seed extruder EZ-150: 1 - reception bunker, 2 - vibrofeeder, 3 - screw, 4 - pressing annular matrix, 5- motor, 6 - thermocouples, 7 - control desk 
Extruder works in the following way. Product comes to bunker 1 from external supply system. After switching on the electric motor 5 and then vibrofeeder 2, mixture is supplied from bunker 1 by vibrofeeder in the working zone of screw part through the reception funnel with magnet-catcher. During the movement on tract of the screw working zone 3, made by spiral channels and glasses ribs, mixture is crushed and pressed out through the central port of outcome screw bush 3. Heating up of the mixture takes place at the expense of force internal friction and at the expense of friction between mixture and screws and basic parts. Ready product comes out through the central port of outcome bush as jet or braid. Extruder is completed with the short spinnerets that are not cooled that allows receive products of porous macrostructure. If appears a necessity in crushing product, extruder is completed with cutter.

For acceleration of extruder starting the matrix was preliminary heated up to the temperature $90 \ldots 100{ }^{\circ} \mathrm{C}$. Regulation of the process temperature and "explosion" coefficient is realized by the change of axis position of outcome bush that is displaced on thread. The change of bush position leads to increase or decrease of clearance between tip and port of outcome bush of the screw part 3 . At that the decrease of clearance leads to increase of the product temperature, increase of product "explosion" coefficient and vice versa.

Before the start of the work ammeter and wattmeter were connected to the set for determination of energy-power characteristics. The indications of these devices were fixed at idling and under load.

Determination was carried out by the way of weighing mass that came out from the outcome port of extruder screw part during $180 \mathrm{~s}$. By the way of recalculation was received the hour set productivity. For reducing productivity to the conventional density $750 \mathrm{~kg} / \mathrm{m}^{3}$ the received productivity value was multiplied by coefficient that was determined by division of conventional density by the actual one.

The power of electric motor at idling and under load was determined by formulas (2), (3):

$$
\begin{aligned}
& \mathrm{N}_{\text {idling }}=\mathrm{I}_{\text {idling }} \cdot \mathrm{U} \cdot \cos \varphi \cdot 10^{-3}, \mathrm{~kW} \\
& \mathrm{~N}_{\text {load }}=\mathrm{I}_{\text {load }} \cdot \mathrm{U} \cdot \cos \varphi \cdot 10^{-3}, \mathrm{~kW}
\end{aligned}
$$

where $I_{\text {idling }}, I_{\text {load }}$ - power of current at idling and under load, A; $\cos \varphi$ - coefficient of phases displacement; $\mathrm{U}$ - tension of current in nets $(380 \mathrm{~V})$.

Electric power consumption was determined by formula (3):

$$
\mathrm{N}_{\text {specific }}=\frac{\mathrm{N}_{\text {load }}-\mathrm{N}_{\text {idling }}}{\mathrm{Q}}, \mathrm{kW}
$$

where $\mathrm{N}_{\text {idling, }}, \mathrm{N}_{\text {load }}$ - power of electric motor at idling and under load, $\mathrm{kW}$; $\mathrm{Q}$ - productivity, kg/year.

After starting up extruder was taken to regime when its productivity, process temperature and power of electric motor current corresponded to the nominal values. Only after attaining this regime the indication of ammeter and wattmeter under load were fixed. Indications were registered with periodicity, accepted depending on mass of outcome raw material and its quality (during 120...300 s). The set productivity was determined under conditions when the consumed power of the main electric motor is $100 \%$, quality of extruded product is satisfactory and temperature corresponds to the specified one $[10,12,13]$.

For determination of technological properties the complex of standard laboratory equipment was used: drying cabinet (EDC) (Fig. 5), dry-air thermostat DT-80M (Fig. 6), purka PX-1 (Fig. 7), dessicator (Fig. 8), densimeter DM2 (Fig. 9), device for determination of the natural slope angle (Fig. 10), sower SL-5M and the set of sieves with round ports with diameter $\varnothing 3, \varnothing 2, \varnothing 1 \mathrm{~mm}$, wire net № 080 and № 056 (Fig. 11), electric ScoutSC 2020-EU1 (Fig. 12) and analytic BLE-200 (Fig. 13) balance. The content of nutritive and biologically active substances was determined using the following devices: Kamovsky electrovacuum pump with dilution $13 \mathrm{~Pa}$ (Fig. 14), photoelectrocolorimeter KPC-2MP (Fig. 15), and also laboratory crockery and reagents according to accepted methods [14]. 


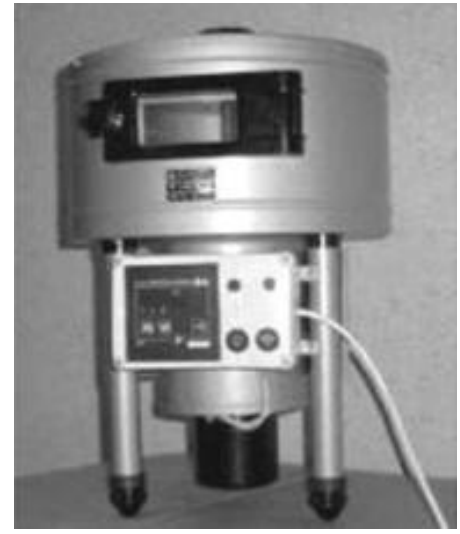

Fig. 5. Electric drying cabinet (EDC-3M (PE SumyCDDandA, Sumy, Ukraine)

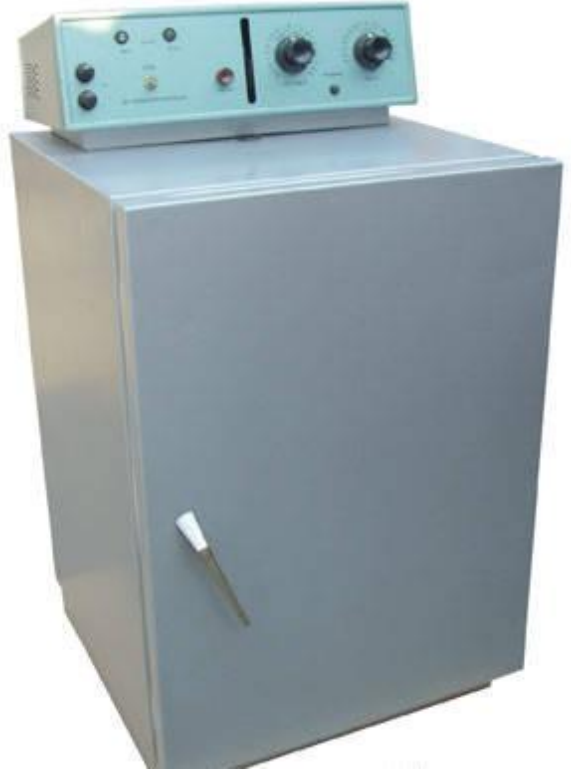

Fig. 6. Dry-air thermostat DT-80M (NPE Podgornaya A. A., Kyiv, Ukraine)

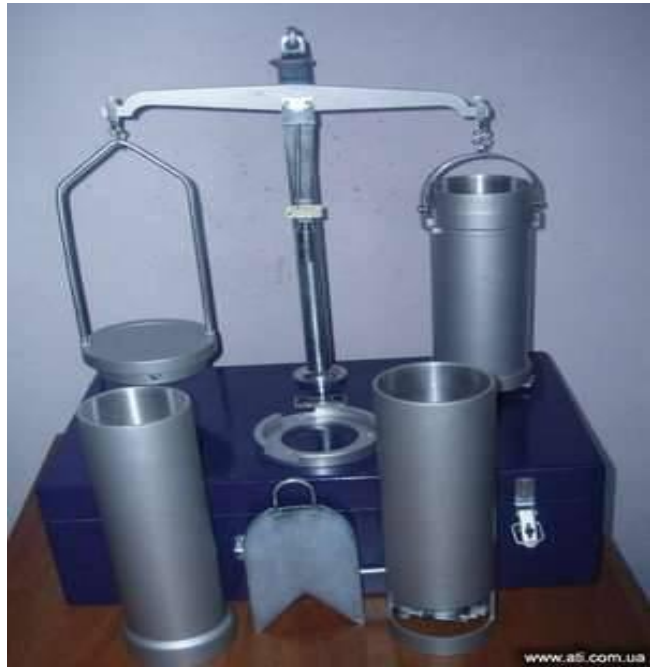

Fig. 7. Liter purka PX-1 (NPE Pashkov, V. A., Dnipro, Ukraine) 


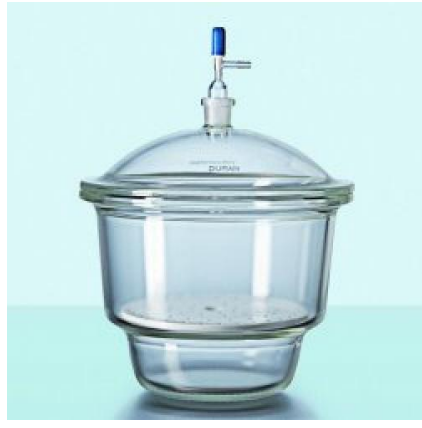

Fig. 8. Dessicator (Parmmedtech COMPANY, Ukraine)

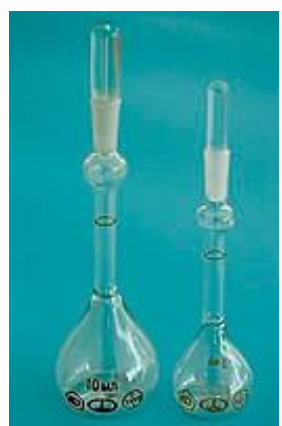

Fig. 9. Densimeter PZ2 (Standard-M, SPF COMPANY, Zaporizhia, Ukraine)

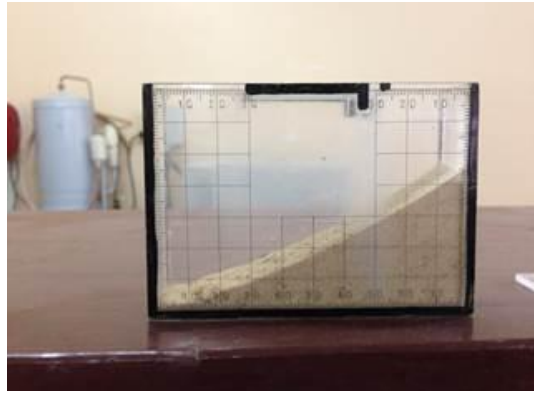

Fig. 10. Device for determination of natural slope angle

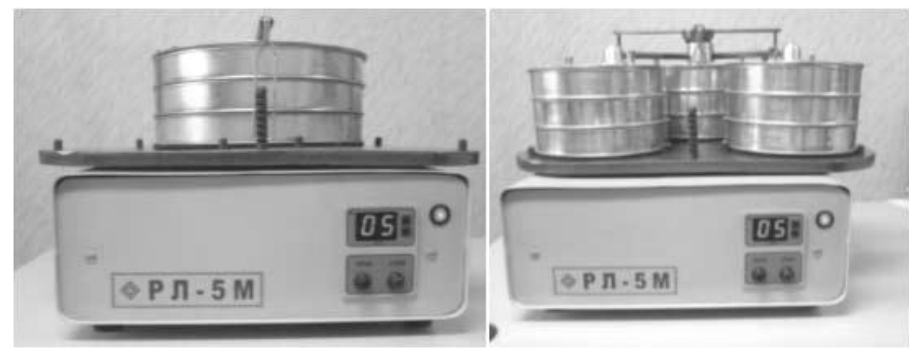

Fig. 11. Sower SL-5M and set of sieves

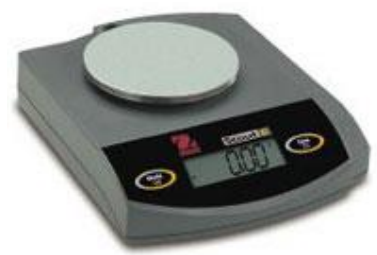

Fig. 12. Electric balances ScoutSC 2020-EU1 

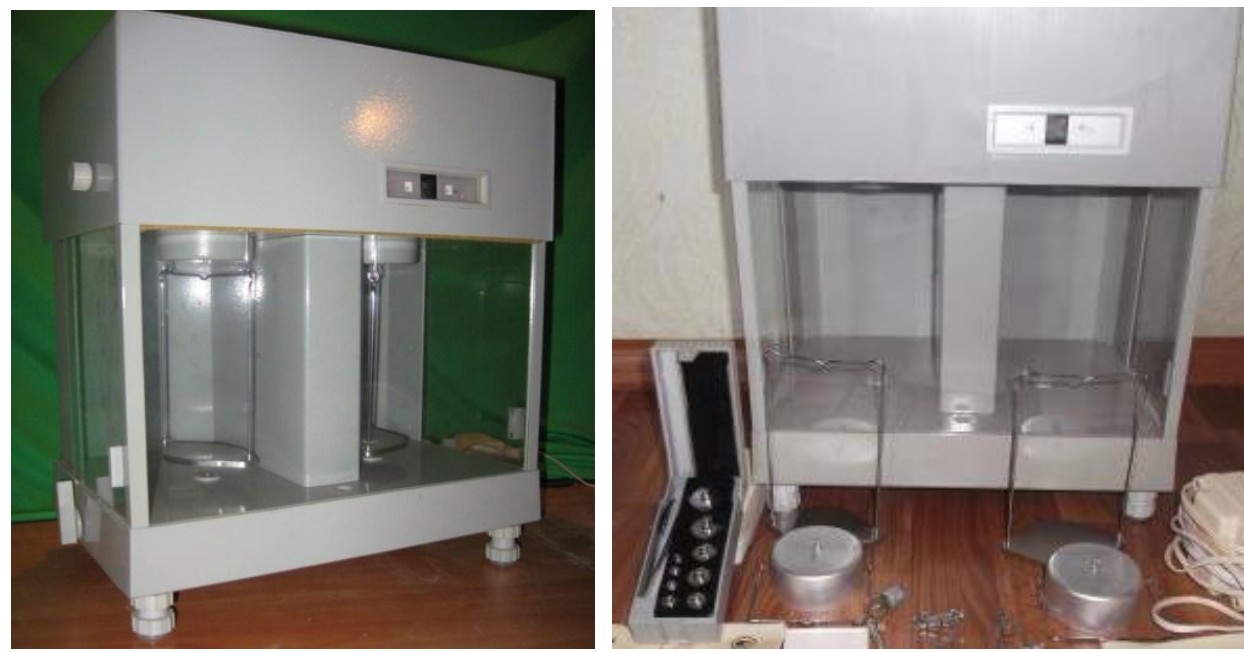

Fig. 13. Analytic balance BLE-200

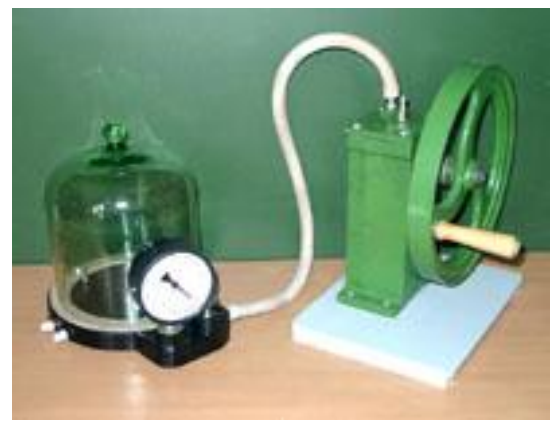

Fig. 14. Kamovsky electrovacuum pump with dilution $13 \mathrm{~Pa}$

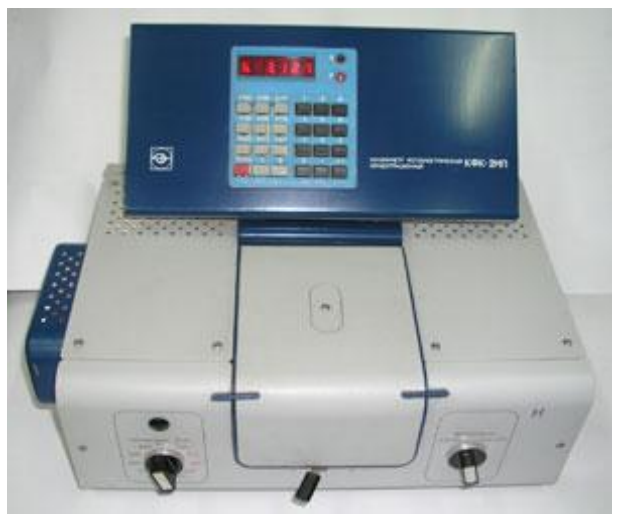

Fig. 15. Photoelectrocolorimeter KPC-2MP (“ZOMF”, Russia)

\section{Results of research}

To get the highly homogenous mixture of crushed corn seed and substandard egg mass it is expedient to carry out two-phased mixing (in frame mixer during $180 \mathrm{~s}$ was received preliminary mixture of components in 1:1 ratio and in mixer with blade mixing device during $120 \ldots 180 \mathrm{~s}$ was realized the main mixing of preliminary mixture of components and crushed corn seed that remained).

Experimental production of EFA samples was carried out on mechanical extruder EZ-150. In extruder was set the matrix with port of diameter $10 \mathrm{~mm}$. In extruding process the pressure in extruder working zone, consumed power of electric motor, temperature of product at outcome of extruder were fixed $2 \ldots 3 \mathrm{mPa}, 4,0 \ldots 4,5 \mathrm{~kW}, 110 \ldots 120{ }^{\circ} \mathrm{C}$ respectively. The process duration was $60 \ldots 120 \mathrm{~s}$. 
As a result of research it was determined, that at introduction in the content of feed additive of $10 \%$ of egg mass without shell the extruding process passes at minimal energy consumption, and the quality parameters of feed additive are the best.

In studied samples of feed additive were determined the changes of physical properties (Table 1), chemical composition (Table 2), amino acid composition of proteins (Table 3) and qualitative-quantitative composition of microflora (Table 4) in extruding process.

Table 1

Influence of extruding on physical properties of feed additive ( $\mathrm{n}=3, \mathrm{P} \geq 0,95)$

\begin{tabular}{|c|c|c|}
\hline \multirow{2}{*}{ Parameters } & \multicolumn{2}{|c|}{ Feed additive } \\
\hline & Before extruding & After extruding \\
\hline Mass part of humidity, $\%$ & 17,1 & 12,8 \\
\hline Natural slope angle, degree & 35,0 & 38,0 \\
\hline Friableness, $\mathrm{cm} / \mathrm{s}$ & 8,6 & 4,6 \\
\hline Volume mass, $\mathrm{kg} / \mathrm{m}^{3}$ & 625,0 & 480,0 \\
\hline Size module, $\mathrm{mm}$ & 1,8 & 1,1 \\
\hline Starch dextrinization degree, $\%$ & 0 & $\mathbf{5 8 , 0}$ \\
\hline Extrudate extension index & \multicolumn{2}{|c|}{2,1} \\
\hline Electrical energy consumption, $\mathrm{kW} \times$ hour & \multicolumn{2}{|c|}{17,0} \\
\hline
\end{tabular}

Analysis of data, given the Table 1 testifies that extruding process positively influences the physical properties of final product.

Table 2

Changes of chemical composition of feed additive in extruding process (in calculation for the dry substance) $(\mathrm{n}=3, \mathrm{P} \geq 0,95)$

\begin{tabular}{ccc}
\hline Parameters & & Feed additive \\
& Before extruding & After extruding \\
\hline Mass part of dry substances, \%: & 82,90 & 87,20 \\
Crude protein & 12,90 & 12,50 \\
Crude fat & 7,60 & 7,50 \\
Water-soluble carbohydrates & 3,90 & $\mathbf{2 3 , 7 0}$ \\
starch & 66,40 & $\mathbf{4 8 , 6 0}$ \\
crude cellulose & 2,20 & 2,10 \\
Crude ash & 1,90 & 1,85 \\
calcium, mg\% & 53,00 & 54,00 \\
phosphorus, $m$ m $\%$ & 348,00 & 340,00 \\
Digestibility of protein, $\%$ & 61,70 & $\mathbf{8 5 , 5 0}$
\end{tabular}

As it can be seen from the data of Table 2 the starch content decreases in extruding process. It is connected with deep gelatinization of seed starch at processing. At that takes place the destruction of starch macromolecules with creation of dextrins and sugars that significantly increases assimilability of the final product. Nutritive properties of protein essentially depend on the duration of thermal processing of product. In the case of short-term process the high result is provided - nutritive value of protein practically does not decrease $[15,16]$.

Extruding was carried out at temperature $110 \ldots 120^{\circ} \mathrm{C}$ during $60 \ldots 120 \mathrm{~s}$ that caused interest of the study of change of amino acid composition of proteins at extruding. 
Table 3

Amino acid composition of proteins of feed additive before and after extruding, $\%$ of $N \times 6,25$ crude protein (in calculation for dry substance) $(n=3, P \geq 0,95)$

\begin{tabular}{|c|c|c|}
\hline \multirow{3}{*}{ Amino acid } & \multicolumn{2}{|c|}{ Feed additive } \\
\hline & Before extruding & After extruding \\
\hline & \multicolumn{2}{|l|}{ Irreplaceable } \\
\hline Valine & 0,68 & 0,62 \\
\hline Isoleucine & 0,52 & 0,47 \\
\hline Leucine & 1,28 & 1,18 \\
\hline Lysine & 0,56 & 0,50 \\
\hline Methionine + cystine & 0,55 & 0,51 \\
\hline Threonine & 0,48 & 0,43 \\
\hline Tryptophan & 0,12 & 0,11 \\
\hline Phenylalanine & 0,62 & 0,61 \\
\hline Together & 4,81 & 4,43 \\
\hline \multicolumn{3}{|c|}{ Replaceable } \\
\hline Alanine & 0,89 & 0,83 \\
\hline Aspartic acid & 1,00 & 0,92 \\
\hline Glycine & 0,46 & 0,45 \\
\hline Glutamic acid & 2,08 & 2,06 \\
\hline Prolin & 0,95 & 0,86 \\
\hline Serine & 0,73 & 0,66 \\
\hline Arginine & 0,67 & 0,61 \\
\hline Histidine & 0,33 & 0,31 \\
\hline Tyrosine & 0,40 & 0,36 \\
\hline Together & 7,51 & 7,06 \\
\hline
\end{tabular}

As in can be seen from the results of the study (Table 3) extruding influences the biological value of protein in feed additive, especially the general content of amino acids in EFA decreased by $6,5 \%$. Moreover the content of irreplaceable amino acids in extruding process decreased by $7,9 \%$, and of replaceable - by $6 \%$.

Table 4

Change of sanitary quality of feed additive in the process of processing and storage in unregulated conditions

\begin{tabular}{|c|c|c|c|c|c|}
\hline Sample & GBS, CCU/g & $\begin{array}{l}\text { Mycelial fungi, } \\
\text { CCU/g }\end{array}$ & Leaven CCU /g & CB titer, $\mathrm{g}$ & Salmonella \\
\hline $\begin{array}{l}\text { Mixture of crushed corn and } \\
\text { egg mass without shell }\end{array}$ & 250000 & 120 & 90 & 0,1 & Was not revealed \\
\hline $\begin{array}{l}\text { Extruded Mixture of crushed corn and } \\
\text { egg mass without shell }\end{array}$ & 1340 & 10 & Was not revealed & $\begin{array}{l}\text { Was not } \\
\text { revealed }\end{array}$ & Was not revealed \\
\hline $\begin{array}{l}\text { Extruded mixture of crushed corn and } \\
\text { egg mass without shell (storage } 1 \text { month) }\end{array}$ & 730 & Was not revealed & Was not revealed & $\begin{array}{l}\text { Was not } \\
\text { revealed }\end{array}$ & Was not revealed \\
\hline $\begin{array}{l}\text { Extruded mixture of crushed corn and } \\
\text { egg mass without shell (storage } 2 \text { months) }\end{array}$ & 460 & Was not revealed & Was not revealed & $\begin{array}{l}\text { Was not } \\
\text { revealed }\end{array}$ & Was not revealed \\
\hline $\begin{array}{l}\text { Extruded mixture of crushed corn and } \\
\text { egg mass without shell (storage } 3 \text { months) }\end{array}$ & 200 & Was not revealed & Was not revealed & $\begin{array}{l}\text { Was not } \\
\text { revealed }\end{array}$ & Was not revealed \\
\hline
\end{tabular}

The results of research, given in the Table 4, indicate that under the complex effect of high temperatures and pressure in extruder working zone takes place disinfection of feed additive. The decrease of general bacterial seeding in the process of storage is connected with low humidity of the studied samples. 


\section{Conclusions}

1. The grounded materials and methods of research are modern and correspond to the requirements of state standards of Ukraine and ISO standards, technical conditions and normative acts [17-21].

2. The study of physical-technological properties of feed additive for poultry testifies that in extruding process is observed insignificant losses of crude protein, starch content decreases by $26,8 \%$ at the expense of increase of its digestibility, namely increase of water-soluble carbohydrate content.

3. In the process of EFA storage in unregulated conditions during three months the level of sample seeding abruptly shortens. EFA must be stored in dry, well ventilated accommodations without humidification and compression. In such case the stable quality parameters and satisfactory sanitary state of product can be guaranteed and this product can be used for feeding poultry during the whole storage term.

4. It was proved, that due to EFA use such valuable and easily assimilated product as egg mass of substandard chicken eggs is used at feeding poultry instead of being missed. The additive can be used in the content of mixed fodder in amount of $15 \ldots .25 \%$ or independently at farms.

\section{References}

[1] Kombikorma: kachestvo, tehnologii, oborudovanie (2014). Kormoproizvodstvo, 7, 46.

[2] Proizvodstvo kombikormov v stranah ES (2014). Kombikorma, 4, 16.

[3] Obzor rynka kombikormov Ukrainy 2015 (2015). Available at: http://marketpublishers.ru/report/industry/agriculture/market_overview_feeds_ukraine_2011.html

[4] Yegorov, B. V. (2011). Tehnologiya vỳ̀robny`cztva kombikormiv. Odesa: Drukars`ky’j dim, 448.

[5] Bol'shinstvo jaic v mire proizvodjat 15 stran (2012). Jaichnyj mir, 2 (16), 76.

[6] Veljamov, M. T., Knjazheva, Zh. K., Kashaganova, Zh. A. (2015). Ispol'zovanie pitatel'noj sredy iz fermentativnogo gidroliza nekondicionnyh kurinyh jaic dlja kul'tivirovanija proizvodstvennyh shtammov na predprijatii. Mezhdunarodnyj zhurnal jeksperimental'nogo obrazovanija, 3, 86-89.

[7] Angelovičová, M., Ševčíková, L., \& Angelovič, M. (2015). The table eggs and their quality in small-scale breeding. Potravinarstvo, 9(1), 442-450. doi:10.5219/515

[8] Chukwuka, O. K., Okoli, I. C., Okeudo, N. J., Udedibie, A. B. I., Ogbuewu, I. P., Aladi, N. O., Omede, A. A. (2011). Egg Quality Defects in Poultry Management and Food Safety. Asian Journal of Agricultural Research, 5(1), 1-16. doi:10.3923/ajar.2011.1.16

[9] Jegorov, B. V., Vorona, N. V. (2011). Pat. 64221 Ukrai’na, MPK A23K 1/10. Dobavka do kombikormu dlja sil's'kogospodars'koi’ ptyci. № u201108847; zajavl. 14.07.2011; opubl. 25.10.2011, Bjul. № 20.

[10] Egorov, B.V., Kochetova, A. A., Mardar, M. R.; Eds. Egorova, B.V. (2004). Metodicheskij ukazanija k vypolneniju laboratornoj raboty po kursu «Uchebno-issledovatel'skaja rabota studentov» dlja studentov, obuchajushhihsja po uchebnomu planu specialistov 7.091701 dnevnoj formy obuchenija. Odessa: ONAPT, 42.

[11] Egorov, B. V., Makarinskaja, A. V., Gonca, N. V. (2009). Teoreticheskie osnovy ocenki odnorodnosti kombinirovannyh smesej. Sbornik nauchnyh trudov MPA, 7 (1), 132-139.

[12] Yegorov, B. V., Makary`ns'ka, A. V., Voyecz'ka, O. Ye., Chajka, I. K.,. Brazhenko,V. Ye.; Eds. Yegorov, B. V. (2010). Metody`chni vkazivky` do vy`konannya laboratorny`x robit z kursu «Texnologiya kombikormovogo vy' robny'cztva» dlya bakalavriv 6.091701 dennoyi i zaochnoyi form navchannya. Odesa: ONAXT, 60.

[13] Yegorov, B. V., Voyecz'ka, O. Ye., Lapins’ka, A. P., Lunina, V. Yu.; Eds. Yegorov, B. V. (2009). Metody'chni vkazivky` do vy'konannya laboratorny’x robit z kursu «Teorety'chni osnovy` xarchovy`x texnologij» dlya studentiv profesijnogo napryamku 6.091701 dennoyi i zaochnoyi form navchannya. Odesa: ONAXT, 60.

[14] Yegorov, B. V., Kochetova, A. O., Vely’chko, T. O., Xorenzhy’j, N. V., Suslo, V. V., Islamov, V. A., Turpurova, T. M.; Eds. Yegorov, B. V. (2013). Kontrol yakosti ta bezpeka produkciyi v galuzi (kombikormova galuz'). Kharkiv: OLDI-PLYuS, 446.

[15] Afanas'ev, V. A. (2002). Teory’ya y’ prakty’ka specy’al'noj obrabotky' zernovыx komponentov v texnology’y` komby’kormov. Voronezh: Voronezhsky’j gosudarstvennыj uny`versy’tet, 296.

[16] Pond, W. G., Church, D. C., Pond, R. R. (1995). Basic animal nutrition and feeding. Fourth edition. New York: John Wiley and Sons, 615.

[17] DSTU 4120-2002 (2002). Kombikormi povnoracionni dlja sil's'kogospodars'koï ptici. Tehnichni umovi.

[18] DSTU 4687:2006 (2006). Kombikormi, premiksi, vitaminni preparati, produkcija ptahivnictva. Metodi viznachennja vitaminiv $\mathrm{A}, \mathrm{E}, \mathrm{B}_{2}$ ta karotinoïdiv.

[19] DSTU 7693:2015 (2015). Kombikormova sirovina. Zagal'ni tehnichni umovi.

[20] GOST ISO 6498-2014 (2014). Korma, kombikorma. Podgotovka prob dlja ispytanij.

[21] DSTU ISO 6887-1:2003 (2003). Mikrobiologija harchovih produktiv ta kombikormiv dlja tvarin. 